\section{O mito da grande classe média: capitalismo e estrutura social. Marcio Pochmann. São Paulo: Boitempo Editorial, 2014, 148p.}

Ramón Peña Castro

Escola Politécnica de Saúde Joaquim Venâncio, Fundação Oswaldo Cruz, Rio de Janeiro, Brasil

<rpena@fiocruz.br>

O redescobrimento das classes sociais representa uma mudança positiva, cada vez mais presente em descrições das novas estruturas sociais dos 'centros' e 'periferias' do capitalismo globalizado. Repare-se que até recentemente a categoria 'classe social' tinha desaparecido do léxico analítico referido à distribuição da riqueza e do poder, ocupando o primeiro plano as problemáticas de gênero, raça, etnia, religião, nacionalidade etc., cuja importância não deve ser subestimada, dada a persistência de odiosas formas de discriminação, desigualdade, violência e criminalidade.

Ao mesmo tempo, não pode ser considerado casual que esse cenário controverso coincida com o declínio das utopias históricas (derrubada do socialismo real e do Estado de bem-estar social, hoje idealizado) concomitante com a expansão da contrarrevolução neoliberal, por um lado, assim como a erosão dos paradigmas culturais através dos quais interpretamos a complexa realidade social, por outro lado.

É, justamente, este cenário controverso o que serve de inspiração para o livro de Marcio Pochmann que passamos a resenhar.

Dividido em quatro partes, cada qual composta de seções que abrangem 15 subtemas, o livro faz jus ao título, pois por sua leitura constatamos que a noção de 'nova classe média' não passa de uma construção quimérica do mercado político.

Na primeira parte, intitulada "Classe média em quatro tempos", o eixo da exposição consiste em um diálogo entre conceituação sucinta das etapas de desenvolvimento histórico do capitalismo e a origem incerta de diferentes usos espaço-temporais do termo 'classe média'. Concluindo com uma reflexão crítica sobre a extemporaneidade deste termo no Brasil, porque a "adoção", escreve Pochmann, "de uma medida descontextualizada da base original da sua materialização pode se revestir apenas e simplesmente de um voluntarismo teórico inconsistente com a realidade, salvo interesses ideológicos específicos ou projetos políticos de reconfiguração da redução do papel [social do] Estado" (p. 45).

A partir deste último raciocínio parece pertinente pensar que a utilização descontextualizada do termo classe média, em substituição do termo classe trabalhadora, também serviria para incutir no ânimo dos trabalhadores a ideia de que seu vínculo unitivo não é o trabalho, mas sim o seu 'novo padrão' de consumo e o correspondente nível de rendimento, descolado da sua origem: a alienação da força de trabalho pelo capital. Por extensão, tudo isto implica a individualização e destruição das solidariedades de classe e das capacidades de (re)ação coletiva.

A segunda parte do livro, intitulada "Classe média: fatos e interpretação no Brasil", contém uma argumentada exposição da origem e características do modelo fordista de desenvolvimento e da composição social do capitalismo avançado do segundo pós-guerra. Na sequência, examina as particularidades da industrialização tardia brasileira e sua relação com as condições de subconsumo da classe trabalhadora, derivadas da resistência das classes dominantes a admitir as reformas estruturais ('civilizatórias') que foram conquistadas (no período 1945/1975) pela esquerda político-sindical nos países desenvolvidos, sem que isso implicasse reversão da ordem capitalista. Pelo contrário, o atual processo de destruição acelerada do 'Estado de bem-estar' demonstra que as conquistas sociais, ligadas a essa denominação otimista (Estado de bem-estar), representam um fenômeno absolutamente excepcional na história do modo de produção capitalista.

Nesta segunda parte do livro, cabe destacar como uma linha de reflexão e debate em aberto a tese de Pochmann sobre "a combinação, na última década, de crescimento econômico brasileiro com distribuição de renda, o que permitiu a retomada da mobilidade social, especialmente aquela associada à base da pirâmide social" (p. 71), incluindo "ascensão dos trabalhadores pobres [no] projeto social desenvolvimentista" (p. 62-70).

Registremos alguns elementos que achamos importantes para compreender o alcance da reflexão de Pochmann sobre a presente trajetória econômica e social do Brasil:

- Ampliação da base da pirâmide social com forte expansão do emprego, com três quartos 
dos novos empregos remunerados até 1,5 salários mínimos;

- Quase $40 \%$ de queda da pobreza em vinte anos: 1988-2008 (p. 67);

- Aumento de quase $80 \%$ do gasto social no PIB, em 25 anos: 13,3\% em 1985 para 22,7\% em 2010 (p. 66).

- Incorporação ao 'mercado de consumo barato' de quase um quarto dos brasileiros, em que "parcela considerável da classe trabalhadora foi incorporada no consumo de bens duráveis, como $\mathrm{TV}$, fogão, geladeira, aparelho de som, computador, entre outros" (p. 71).

Destacamos a sua própria conclusão: "esse importante movimento social", escreve Pochmann, "não se converteu, contudo, na constituição de uma nova classe social, tampouco permite que se enquadrem os novos consumidores no segmento de classe média” (p. 71).

A terceira parte, intitulada "Cadeias globais de produção e ciclos de modernização no padrão de consumo brasileiro", contém análise, assente em numerosos dados estatísticos resumidos em gráficos e tabelas, da dinâmica da economia política de consolidação do capitalismo monopolista transnacional e seus impactos nas estruturas sociais, especificamente no Brasil.

Fazendo um balanço das informações obtidas pela sua consistente exploração bibliográfica e elaboração estatística, Pochmann expõe com singular clareza as três principais razões explicativas da evolução histórica do grau de desigualdade no padrão de bens e serviços civilizados.

A primeira razão explicativa é a globalização como novo paradigma da produção das empresas transnacionais. Assente não apenas nas novas tecnologias, mas sobretudo em políticas neoliberais de liberalização dos mercados e privatização do setor público, assim como na ampliação da base de recursos produtivos, matérias e humanos, como decorrência da restauração do capitalismo na União Soviética, Leste europeu e China, principalmente. Essa enorme expansão geográfica dos mercados significou um aumento de 1,5 para 3,9 bilhões do exército de força de trabalho fragmentada em estados competidores. Tudo isso tornou possível a produção massiva de todo tipo de mercadorias de baixo custo e sobre esta base a emergência das sociedades de consumo de baixo custo (low cost).

A segunda razão explicativa é a especificidade da inserção do Brasil na divisão internacio- nal do trabalho, mostrada por meio da sucessão dos ciclos de modernização do padrão de consumo das distintas faixas de renda, ocupação setorial e grau de escolaridade, assim como a alteração sucessiva dos preços relativos. Trata-se de uma análise aprofundada de informação estatística abrangente, apresentada em tabelas e gráficos elucidativos.

A terceira razão explicativa da evolução das desigualdades, num sentido positivo, são as políticas sociais compensatórias, a bancarização de setores de menor renda, incluindo a expansão do crédito para consumo de bens duráveis e novos serviços. Na contraface dessas alterações encontra-se, sem dúvida, a mercantilização da vida e a financerização da sociedade.

Sabendo que a sociedade envolve muitas atividades e relações (de poder, de consciência, culturais, nacionais, sexuais, normativas etc.) que não concernem à Economia Política, o autor concentrou-se na temática da estrutura social, nitidamente transbordada da realidade por força do superdimensionamento fictício quando se fala de uma grande e nova classe média.

A quarta e última parte do livro concentra-se no exame da superação relativa da imobilidade social na primeira década deste século. Após a longa fase de regressão e estagnação da estrutura social das duas décadas anteriores, parece consolidar-se uma onda de novas ocupações e uma incerta política de rendas que visa à curva de distribuição da renda de $40 \%$ da população mais pobre. A identificação desses segmentos e o estudo da evolução geral da ocupação e do rendimento mostrariam, segundo Pochmann, sinais significativos da "volta da mobilidade social ascendente, sobretudo, na base da pirâmide social brasileira, que nada tem de nova, tampouco de classe média" (p. 139). 